\title{
Using Low-Volatility Dicamba in Dicamba-Tolerant Crops $^{1}$
}

\author{
P. Devkota and J. A. Ferrell ${ }^{2}$
}

\section{Herbicide Selection}

After many years in development, dicamba has been fully approved for use in the dicamba-tolerant (DT) crops or XtendFlex cotton and soybean varieties. With the wider use of dicamba and numerous off-target injury cases, there is huge concern that off-target movement of dicamba can result in significant damage to nearby sensitive crops. This concern is well-founded because many crops (such as soybean, cotton, snap bean, peanut, and watermelon) are highly sensitive to very low doses of dicamba. All precautions must be followed if the newer dicamba formulations are to be used in DT cotton or soybean. In December 2020, the herbicide labels for three products containing newer dicamba formulations (XtendiMax, Engenia, and Tavium) were updated; these are valid for the next five years. The fourth herbicide product containing newer dicamba (i.e., FeXapan) has been discontinued by Corteva Agriscience. These new labels provide important details about dicamba product selection, tank-mix products, avoiding use of ammonium sulfate, nozzle selection, buffer requirement, boom height, wind speed, and ground speed, as well as the use of volatility reduction adjuvants or drift reduction technology. This publication is relevant to the growers and pesticide applicators who are applying newer, low-volatility formulations of dicamba herbicide products in DT crops. It is also an important resource for UF/IFAS Extension agents who provide information related to dicamba application to the appropriate stakeholders.

Dicamba has been available and widely used in corn, small grain, and pastures for over 50 years. There are many different brands of dicamba in the marketplace. However, it is essential that only products approved for use in DT crops be used. The approved herbicides are XtendiMax from Bayer CropScience, Engenia from BASF, and Tavium from Syngenta. These specific herbicides must be used because they have been engineered to have very low volatility, or low potential to turn into a gas after application, while maintaining full herbicidal potency. Moreover, these four products can only be applied on DT cotton and soybean. Using a Banvel- or Clarity-type herbicide over the top of dicamba-tolerant cotton or soybeans is illegal.

\section{Tank-Mix Products}

Not all herbicide or pesticide products are compatible with newer dicamba formulations. Only certain products recommended in the XtendiMax, Engenia, and Tavium label can be tank-mixed. The information on appropriate tank-mix products is listed on the website from the respective registrant company. The restriction for tank-mixing certain products is to protect the low-volatility formulations

1. This document is SS-AGR-412, one of a series of the Agronomy Department, UF/IFAS Extension. Original publication date February 2017. Revised June 2020 and March 2021. Visit the EDIS website at https://edis.ifas.ufl.edu for the currently supported version of this publication.

2. P. Devkota, assistant professor, Agronomy Department, UF/IFAS West Florida Research and Education Center; and J. A. Ferrell, professor, Agronomy Department, and director, UF/IFAS Center for Aquatic and Invasive Plants; UF/IFAS Extension, Gainesville, FL 32611.

The use of trade names in this publication is solely for the purpose of providing specific information. UF/IFAS does not guarantee or warranty the products named, and references to them in this publication do not signify our approval to the exclusion of other products of suitable composition.

The Institute of Food and Agricultural Sciences (IFAS) is an Equal Opportunity Institution authorized to provide research, educational information and other services

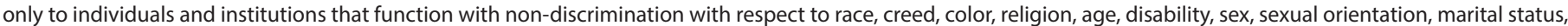

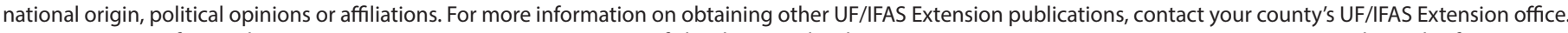
U.S. Department of Agriculture, UF/IFAS Extension Service, University of Florida, IFAS, Florida A \& M University Cooperative Extension Program, and Boards of County Commissioners Cooperating. Nick T. Place, dean for UF/IFAS Extension. 
and to decrease dicamba off-target movement. Tank-mixing incompatible products can lead to significant dicamba volatility, off-target movement, and severe injury to the sensitive crops. Complete listings of the recommended tank-mix products for each dicamba herbicide can be found below.

- XtendiMax (https://www.xtendimaxapplicationrequirements.com/Pages/tankmix.aspx\#/search)

- Engenia (https://www.engeniaherbicide.com/tank-mix. html)

- Tavium (http://www.syngenta-us.com/herbicides/ tavium-tank-mixes)

\section{Ammonium Sulfate}

Ammonium sulfate should never be added with XtendiMax, Engenia, and Tavium. Adding ammonium sulfate, the principal component of many water conditioners sold at the retail level, creates unique chemical forces in the spray solution that convert low-volatility dicamba into its most volatile form. Adding any ammonium sulfate product negatively impacts low-volatility technology that has been engineered into the XtendiMax, Engenia, or Tavium formulations.

\section{Buffer Requirement}

Buffer is required for XtendiMax, Engenia, and Tavium application. A 240 -foot downwind buffer is required for dicamba application in counties where endangered species are not listed. For counties where endangered species are present, the downwind buffer is $310 \mathrm{ft}$ and omnidirectional buffer (on all sides) is 57 feet. At present, endangered species are listed in five Florida counties: Jackson, Washington, Calhoun, Gadsden, and Bay. However, this list can change based on updates from the EPA. Therefore, the EPA's website for endangered species (https://www.epa. gov/endangered-species/bulletins-live-two-view-bulletins) should be followed for the most accurate information. Even though a buffer is in place, it is important not to spray when the wind is blowing towards nearby sensitive crops or residential areas. The use of approved hooded/shielded sprayers allows for reducing the downwind buffer requirement. Follow the label or product stewardship websites for detailed information on reducing buffer requirements.

\section{Nozzle Selection}

Nozzles create a range of droplet sizes from fine to coarse or ultra-coarse. The percentage of small droplets formed and those small droplets' ability to drift are issues that users of each nozzle must take into account. The EPA has reviewed many different nozzles over a wide range of operating pressures. This information indicates that only certain nozzles and pressure combinations are appropriate for application of herbicides such as XtendiMax, Engenia, and Tavium. For a current list of approved nozzles for XtendiMax, Engenia, and Tavium, see the links provided below. These lists will continue to be updated, so check these websites routinely for the most current information. Note that use of any nozzle not specifically approved and listed on these websites would be considered a misuse.

- XtendiMax (https://www.xtendimaxapplicationrequirements.com/Pages/tankmix.aspx\#/nozzles)

- Engenia (https://www.engeniaherbicide.com/tank-mix. html)

- Tavium (https://www.syngenta-us.com/herbicides/ tavium-tank-mixes)

\section{Nozzles}

Last Updated on February 12, 2020

\begin{tabular}{|c|c|c|c|c|c|c|c|c|c|c|}
\hline \multirow{2}{*}{ Manulacturer } & \multirow{2}{*}{ Norte Type } & \multirow{2}{*}{ Part Number } & \multicolumn{8}{|c|}{ Operating Pressure (psi) } \\
\hline & & & 20 & 30 & 40 & 50 & 60 & 70 & 80 & 90 \\
\hline \multirow{6}{*}{$\begin{array}{l}\text { Greerieat } \\
\text { Tectnologies }\end{array}$} & TADFO3. D & TADFO3.O & $\operatorname{Min} 20$ & & $\operatorname{Max} 40$ & & & & & \\
\hline & TADHOS-D & TADFOE-D & $\operatorname{Min} 20$ & & & $\operatorname{Max} 50$ & & & & \\
\hline & TDXL 11003-D & TOXL 21003-D & $\operatorname{Min} 20$ & & $\operatorname{Max} 40$ & & & & & \\
\hline & TOXL.11004-D & TOXL 11004-D & $\operatorname{Min} 20$ & & & $\operatorname{Max} 50$ & & & & \\
\hline & TDXL 11005-D & TDXL 11005-D & $\operatorname{Min} 20$ & & & & $\operatorname{Max} 60$ & & & \\
\hline & TDXL 11006-D & TOXL 11006-D & $\operatorname{Min} 20$ & & & & $\operatorname{Max} 60$ & & & \\
\hline \multirow{6}{*}{ Pentair Hypro } & บLเ120-04 & $\begin{array}{l}\text { ULD120.04/ } \\
\text { SC-ULD120-04 }\end{array}$ & $\operatorname{Min} 20$ & & $\operatorname{Max} 40$ & & & & & \\
\hline & ULO120-05 & $\begin{array}{l}\text { ULD120.05/ } \\
\text { FC.ULD120.05 }\end{array}$ & $\operatorname{Min} 20$ & & $\operatorname{Max} 40$ & & & & & \\
\hline & ULDM130-03 & ULOM130.03 & & $\operatorname{Min} 30$ & & & $\operatorname{Max} 60$ & & & \\
\hline & ULDMU130-24 & บLDM130.04 & & $\operatorname{Min} 30$ & & & & & & $\operatorname{Max} 90$ \\
\hline & UIDME130-05 & ULDMi30-05 & & $\operatorname{Min} 30$ & & & & $\operatorname{Max} 70$ & & \\
\hline & ULDM130-06 & ULOM130.06 & & $\operatorname{Min} 30$ & & & $\operatorname{Max} 60$ & & & \\
\hline \multirow{5}{*}{ John Deere } & UL0120.04 & $\begin{array}{l}\text { PSULD20004/ } \\
\text { PSULLDO2004 }\end{array}$ & $\operatorname{Min} 20$ & & Max 40 & & & & & \\
\hline & vLD120.05 & $\begin{array}{l}\text { PSULDO2005/ } \\
\text { PSULLQ2005 }\end{array}$ & $\operatorname{Min} 20$ & & $\operatorname{Max} 40$ & & & & & \\
\hline & PSULDMasoos & Еรиเомов:003 & & $\operatorname{Min} 30$ & & & $\max 60$ & & & \\
\hline & PSULDMq3004 & FSULDMC3004 & & $\operatorname{Min} 30$ & & & & & & $\operatorname{Max} 90$ \\
\hline & PSULDMO3005 & PSULDMC3005 & & $\operatorname{Min} 30$ & & & & $\operatorname{Max} 70$ & & \\
\hline
\end{tabular}

Figure 1. List of nozzles and pressures that can be used to apply XtendiMax herbicide.

Credits: Reprinted with permission from Bayer

CropScience. Accessed on February 25, 2020. https://www.

xtendimaxapplicationrequirements.com/Pages/default.aspx\#/nozzles

\section{Boom Height}

Controlling the spray boom height above the crop canopy is essential to reducing drift. With appropriate boom height, the droplet is less likely to move off-site. For this reason, a maximum boom height of 24 inches above the target weed or crop canopy is recommended in the dicamba herbicide products label. Exceeding this height dramatically increases drift potential. 


\section{Wind Speed}

It is essential to pay close attention to wind speeds before and during dicamba application. The newer dicamba product label recommends wind speed to be 3-10 mph for dicamba application. XtendiMax, Engenia, and Tavium are not exempt from the $10 \mathrm{mph}$ maximum wind speed that has been in the Florida Organo-Auxin Herbicide Rule (Florida Department of Agriculture and Consumer Services 2010) for over 30 years. Records of wind speed and direction need to be kept closely. Spraying must cease if the wind speed/gust exceeds $10 \mathrm{mph}$ or if the wind blows toward a sensitive crop.

\section{Ground Speed}

Spraying at the appropriate speed is essential for reducing off-target movement. Higher ground speed may result in a vortex effect (where spray droplets circulate in a spiral pattern) behind the sprayer and contribute to off-target movement. The ground speed cannot exceed $15 \mathrm{mph}$ while spraying, and $5 \mathrm{mph}$ is recommended while spraying field edges. Spray volume is also an important factor; therefore, newer dicamba products are required to spray at a minimum of 15 GPA.

\section{Application Timing}

If low-lying temperature inversion conditions exist, then XtendiMax, Engenia, and Tavium should not be sprayed. There is higher risk for off-target dicamba movement if spraying occurs during temperature inversion. The cool conditions near the ground, low-lying layer of fog, or presence of dew represent the temperature inversion condition. A temperature condition will most likely occur in the evening just after sunset and can persist through the early morning hours. Perfectly still conditions can prevent air mixing, leading to inversions. This is why the label requires a minimum wind speed of $3 \mathrm{mph}$ before spraying can occur. Furthermore, the dicamba products should only be sprayed one hour after sunrise and two hours before sunset. There is also a cutoff timing for dicamba application based on crop: June 30 for DT soybean and July 30 for DT cotton. Dicamba cannot be applied on these crops after their designated cutoff dates. In addition, there is a maximum of two dicamba applications allowed over the top of DT soybean or cotton per year.

\section{Recordkeeping}

Detailed recordkeeping is mandatory for XtendiMax, Engenia, or Tavium herbicide application. Applicators must generate records within 72 hours after applying these herbicides and retain the records for at least two years. Individual application records should include information on the applicator, product used, application parameters, buffer and adjuvant used, tank-mix products, buffer placement, weather conditions (temperature, wind speed and direction, relative humidity, etc.), and tank cleanout. A separate record must be maintained for each field or application. The detailed information for recordkeeping is listed on the herbicide product label. The recordkeeping form is also available at the registrant's product stewardship websites.

\section{Frequently Asked Questions}

\section{Why are these restrictions important?}

This is a conditional federal registration, which is quite uncommon. This means that the registration is time-limited and will expire in December 2025 if the EPA does not extend it. At that time, the EPA will assess how many drift complaints or fields with documented resistance have been filed and determine if these numbers are too high to justify the full registration of XtendiMax, Engenia, and Tavium in cotton and soybeans. Therefore, it is essential to continue rotating herbicide chemistry and using preemergence herbicides to reduce the likelihood of resistance development. It will also be essential to observe the buffer zone, nozzle selection, tank-mix products, and wind speed requirements to ensure that drift does not occur.

\section{Can I continue to use conventional 2,4-D or dicamba formulations in non-dicamba crops?}

Yes. However, you must follow the instructions on the label for that specific herbicide. For example, Banvel must be applied 21 days (plus rainfall) before cotton can be planted. XtendiMax, Engenia, and Tavium can be applied preplant or at planting, or over the top in dicamba-tolerant crops. Older formulations may provide an economic advantage, but the newer formulations will provide application flexibility (can be applied over the top on dicamba-tolerant crops). Regardless of which dicamba or 2,4-D product is used, the Florida Organo-Auxin Herbicide Rule (Florida Department of Agriculture and Consumer Services 2010) must be followed.

\section{Can I tank-mix dicamba (XtendiMax, Engenia, FeXapan, or Tavium) with glufosinate or glyphosate?}

Currently, certain formulations of glyphosate are an allowed tank-mix partner, but glufosinate is not. There are several 
tank-mix partners allowed with XtendiMax, Engenia, and Tavium. Refer to the links above for lists of approved tank-mix products for each dicamba herbicide formulation.

\section{Are there special licensing requirements to purchase or apply these herbicides?}

Yes. Newer dicamba formulations are "Restricted Use Pesticides," and only certified applicators with valid RUP Licenses are allowed to purchase, mix, and apply XtendiMax, Engenia, and Tavium herbicides. In addition, dicamba applicators are required to attend an annual Florida Dicamba Stewardship Training organized by UF/ IFAS Extension (https://ifas-pest.catalog.instructure.com/ courses/pice-2021-dicamba-stewardship-training). Upon completion of this training, a certificate will be issued for proof of attendance, which must be kept on record for two years and made available upon the audit/request of the regulatory personnel/agency.

\section{Are there special tank clean-out procedures?}

Use a pressure rinse or the following triple-rinse procedure: a) water; b) detergent-based cleaner, commercial tank cleaning solution, or 3\% ammonia solution; and c) water. These make up the standard cleanout procedure after dicamba application. Do not let dicamba sit in the sprayer overnight or for extended hours. Doing this will make it much more difficult to effectively clean the tank.

\section{Is special recordkeeping required to comply with the FDACS Organo-Auxin Herbicide Rule?}

Yes. In addition to mandatory recordkeeping for XtendiMax, Engenia, and Tavium herbicide applications, further information must be recorded for applicators to be in compliance with the Florida Organo-Auxin Rule. This is available at https://www.flrules.org/Gateway/View_notice. asp?id=1007265. The information required for the Florida Organo-Auxin Rule includes:

- Name and address of owner or tenant and the applicator

- Location of the treatment site, total acreage, mix/load area, description of application equipment, and hourly wind speed

- Product manufacturer, trade name, formulation, and total amount of product and active ingredient applied per acre

- Nozzle type used, output (GPM) rating at certain pressure, and angle of spray emission if applicable

\section{References}

Florida Department of Agriculture and Consumer Services. 2010. “5E-2.033 Organo-Auxin Herbicides: Restrictions and Prohibitions." Florida Department of State Florida Administrative Code \& Florida Administrative Register. Accessed on February 20, 2017. https://www.flrules.org/ gateway/ruleno.asp?id=5E-2.033

Bayer CropScience. 2021. "Nozzles." XtendiMax ${ }^{\text {tm }}$ Herbicide with VaporGrip ${ }^{\mathrm{Tn}}$ Technology. Accessed on February 25, 2021. https://www.xtendimaxapplicationrequirements.com/ Pages/default.aspx\#/nozzles 